\title{
Building professional identity: a study with female managers who are baby boomers, generation Xers, and millennials
}

\author{
Marlene Catarina de Oliveira lopes Melo ${ }^{1}$ \\ Vilma Santos Pereira de Faria ${ }^{1}$ \\ ANA LÚCIA MAGRI LOPES ${ }^{1}$ \\ ${ }^{1}$ Centro Universitário Unihorizontes / Programa de Mestrado em Administração, Belo horizonte - MG, Brazil
}

\begin{abstract}
This article analyzes the construction of the professional identity of female managers who are baby boomers, generation Xers and millennials. The research adopted a qualitative and analytical descriptive approach, interviewing 32 women working in different sectors of the economy in the city of Belo Horizonte, Brazil. The group interviewed was chosen and divided by generations counting on 06 baby boomers, 11 generation Xers, and 15 Millennials. The data were analyzed considering the dimensions proposed by Hill (1993) when discussing the process of becoming a manager: learning what it means to be a manager; developing interpersonal judgements; gaining self-knowledge; coping with stress and emotions; and managing transformations. The study identified that although the generations have different characteristics (such as way of thinking, acting, and seeing the world), they have little influence in the process of building professional identity of the female managers.
\end{abstract}

Keywords: Professional identity. Managers. Generations.

\section{A construção da identidade profissional: estudo com gestoras das gerações Baby Boomers, Xe Y}

\section{Resumo}

O objetivo deste estudo foi o de analisar a construção da identidade profissional de mulheres pertencentes as gerações Baby Boomers, $\mathrm{X}$ e $\mathrm{Y}$, que atuam como gerentes. Em termos metodológicos, este estudo adotou uma abordagem qualitativa-descritiva e entrevistou 32 mulheres que atuam como gerentes em diversificados setores da economia, localizados na cidade de Belo Horizonte. O grupo entrevistado foi constituído por 6 gestoras da geração Baby Boomers, 11 da geração X e 15 da geração Y. Os dados foram analisados considerando as seguintes categorias propostas por Hill (1993): "aprender o que significa ser gerente", "desenvolver julgamentos interpessoais", "adquirir autoconhecimento", "lutar contra as tensões e emoções" e "gerenciar as transformações". Como principal achado, observou-se que, embora as gerações em estudo apresentem características distintas, como modo de pensar, agir e ver o mundo, tais diferenças pouco interferem no processo de construção da identidade gerencial.

Palavras-chave: Identidade profissional. Gerentes. Gerações.

La construcción de la identidad profesional: una investigación con gerentes femeninos de las generaciones Baby Boomers, $\mathrm{XeY}$

\section{Resumen}

Este artículo se propuso analizar la construcción de la identidad profesional de las mujeres gerentes pertenecientes a las generaciones Baby Boomers, X e Y. Se aplicó la metodología con abordaje cualitativo-descriptivo. Se entrevistaron 32 gerentes femeninos de sectores diversificados de la economía, de la ciudad de Belo Horizonte, estado de MG. El grupo entrevistado estaba compuesto por 06 gerentes de la generación Baby Boomers, 11 de la generación X y 15 de la generación Y. Los datos se analizaron considerando las categorías propuestas por Hill (1993), a saber: "aprender qué significa ser gerente"; "desarrollar juicios interpersonales"; "adquirir autoconocimiento"; "luchar contra las tensiones y emociones" y, "gestionar las transformaciones". El principal hallazgo fue la percepción de que aunque las generaciones en estudio poseían características diferentes, como: forma de pensar, actuar y ver el mundo, esas diferencias poco interfieren en el proceso de construcción de la identidad gerencial.

Palabras clave: Identidad profesional. Gerentes. Generaciones. 


\section{INTRODUCTION}

Managerial functions have been studied for years in the field of administration and understanding them demands more than identifying attributions; it is essential to consider their contradictions, ambiguities, and constant changes. It infers studying themes such as the dynamics and conflicts of the capitalist system, the power relations within the organizations, the difficulties of establishing the harmony of the managerial function with personal and family matters. From the empirical point of view, being a professional manager is a challenge, since these workers are in a permanent unstable situation when facing the various interests involved in performing managerial functions (VENTURA and MAGESTE, 2016).

When taking on managerial functions, the subject starts a process of building a professional identity through constant socialization. Building identity is a process that goes beyond personal efforts or natural talent. It is a process that encompasses the individual's personal and professional life, their particular judgments and the judgment of others, as well as the experience of constantly changing relationships (DUBAR, 2005).

According to Hill $(1993$, p. 6), professional identity is socially constructed and relies on successive dimensions, such as: "learning what it means to be a manager"; "developing interpersonal judgments"; "gaining self-knowledge"; "coping with stress and emotions" and "managing the transformation" necessary in the process of self-development. This study adopts the notion by Hill (1993) and Dubar (2005) that building managers professional identity occurs through specific moments of their experience while performing managerial functions and, based on this premise, seeks to analyze the construction of the professional identity of female managers from different generations (baby boomers, generations $X$, and millennials). The research was conducted through qualitative and descriptive methods, interviewing 32 women in managerial positions in the areas of banking, technology, and public sector, in the region of Belo Horizonte (MG), Brazil.

The way people from different generations perceive reality is an issue studied to help explain the professional's behaviors, as well as understanding their needs, expectations, and aspirations regarding the labor market and the behavioral changes that affect the individual's functional and managerial structure within organizations (LANCASTER and STILLMAN, 2011). In this context, this article seeks to contribute to expand and advance the research on building professional identity of female managers, observing these professional's behavior related to their generation. The next section of the article introduces the context of the research, including a theoretical framework focused on managerial identity in Hill's (1993) perspective and generations. The following section presents the methodology, followed by the analysis of the findings based on the interviews and the final considerations and references.

\section{COMPLEXITY OF MANAGERIAL FUNCTIONS}

The study of managerial functions is not a recent topic in administration. The literature seeking to comprehend the managerial roles and skills has been produced since the beginning of the twentieth century (FAYOL, 1964; MINTZBERG, 1973; KOTLER, 1982; HILL, 1993; SILVA, 2008). Fayol (1964) considers that management is an activity that involves forecasting and planning, organizing, commanding, coordinating, and controlling. For the author, the manager's function is to lead the organization to ensure the implementation of these five aspects, obtaining advantage and maximizing resources. Therefore, the study on planning, systematization, management, administration, and control - as means of speculative conception of the managerial function - has been a practice in the field of administration for more than a century (PAIVA, ESTHER, PIRES et al., 2006).

The study by Mintzberg (2010) challenges Fayol's managerial functions. Mintzberg observed managers in their professional dayto-day while they worked to prevent organizational disorder by solving one problem after another, without a pre-established functional sequence. The characteristics presented by Mintzberg (2010, p. 31) challenge some of the myths created around the management practice. The author recognizes that managers are not continually planning, organizing, commanding, coordinating, and controlling, as Fayol stated. 
Since his first work, Mintzberg (1973) clarifies that managers act as social actors playing three distinct roles: interpersonal role, information role, and decision-making role. The author argues that managers must be able to play these roles according to the organization's demand in intra- and inter-organizational contexts. In the same way as Mintzberg (1973), Hill (1993) challenged Fayol's (1964) position by recognizing that managers act as social actors. The author studied newly promoted managers and, when questioning these professionals about their views on being in this position, the responses were not "being the person in control," as the functions posed by Fayol (1964) suggested. Among the responses obtained in the study by Hill (1993), managers saw themselves as 'troubleshooters,' 'jugglers,' and 'quick-change artists.'

In a study conducted by Allard-Poesi (2015), the participating managers did not agree on the managerial role. The participants' concept of managerial function was marked by contradictions and nuances, which is a result also found in the study by Melo (1994). Allard-Poesi (2015) noted that the definition of the managerial role is complex and changes among the professionals, which led the author to adopt the metaphor "dancing in the dark" when referring to the issue. The complexity of the managerial function requires managers to develop several skills, which influence the construction and maintenance of managerial identity. Melo (2002) considers that the manager still needs to exercise a political function to accommodate the interests of the groups, through interpersonal relationship and the ability to hide conflicts.

\section{IDENTITY}

"Identity" and "identity processes" are among the most debated topics in the study of organization and management (ALVESSON, ASHCRAFT and THOMAS, 2008; COUPLAND and BROWN, 2012; YBEMA, KEENOY, OSWICK et al. 2009). Several factors influence, transform and build the individual's identity, which is connected to the process of forming a managerial identity. This construction is continuously affected by daily events, religion, relationships, social and cultural pressures, expectations, economic context, and the characteristics of the organizational world. Many elements influence the construction of identity processes since professional choice and performance are responsible for transforming professional identity (RODRIGUES, 2016).

Dubar $(1997,2005)$ argues that 'self-identity' and 'self-identity for the other' are connected. According to the author, they correlate because the individual knows who they are, based on how others see them. Therefore, the person builds identity from the connections and influences of the family, society and organizational world, as well as from their interest and life experience. Ybema, Keenoy, Oswick et al. (2009, p. 301) define the construction of identity as "a complex, multifaceted process which produces a socially negotiated temporary outcome of the dynamic interplay between internal strivings and external prescriptions[...]," aiming to understand the processes of the organization (BROWN, 2001; LOK, 2010). Thus, given the dynamic and procedural variety of the theme "identity" and following various observations from temporal, historical, political, and ontological perspectives that allow for identity changes over time, identity construction cannot be considered as a passive situation (ÉSTHER and MELO, 2008).

\section{Professional identity according to Linda Hill}

Managers who just started in the position have a limited perception of what the job entails because they are not considered capable of finding the aim and the meaning of their role. However, they agree that "the managerial role is a complex and demanding one" (HILL, 1993, p. 11). In the exercise of the managerial function, these professionals are required to 'juggle' the many responsibilities imposed on them, as well as being constantly involved with people who have multiple and often conflicting demands. The individual ceases to be a mere expert and executor and becomes a person who understands the organization better, who has comprehensive knowledge. The author considers that, by assuming the managerial identity, the subject becomes more concerned with the activities performed by others than with their own. 
For this reason, it is essential for new managers to develop the elementary characteristics of the managerial role, such as the ability to work with networks, help others to perform their activities, interact with subordinates, have an expanded view of the organization, work towards meeting and assimilating the working network needs, and deliver results. There is a series of real and metaphoric 'confabulations' occurring in the construction of this managerial identity, which goes through five dimensions, according to Hill (1993).

For Hill (1993), the first dimension is related to acquiring knowledge and the perception that managers have about their expectations and the expectations of their peers, subordinates, and superiors, about the performance of the managerial function. In this phase, new managers develop more open and strategic and collective thinking, resulting in networking. Also, the priority for them is setting the agenda. In the second dimension, these professionals learn about the exercise of authority, control, and delegation, as well as developing the capacity to perform interpersonal judgment.

In the third dimension, they gain self-knowledge by understanding themselves both as a person and as a manager. The professional becomes aware of their strengths and weaknesses. In the fourth dimension, new managers understand that leading people is more important than leading tasks, consolidating the managerial behavior. In this dimension, managers deal with job tensions, conflicts, fears, anxieties, and ambiguities, which are sources of stress when the process of identity metamorphosis starts. In the fifth dimension, the author points out how a professional becomes a manager, debating the process of transformation.

Against this backdrop, Hill (1993) considers that the construction of managerial identity starts in the first year of the managerial career, with the professional's experiences. Throughout their professional life, managers learn to deal with new situations, emotions, and tensions that contribute to the process of construction and consolidation of the managerial identity. This process is manifested in different ways according to the generation of the managers.

\section{GENERATIONS}

The labor market is heterogeneous, formed of groups with different characteristics. The workers' age is one of the most important differences, influencing people's behavior according to their age group (STRAUSS and HOWE, 1991; FALASTER, FERREIRA and REIS, 2015; KRUGER and SAAYMAN, 2015; VELOSO, DUTRA and NAKATA, 2016). Seeking a better understanding of the divergences and convergences of the generational groups and how much these aspects impact on contemporary society, the study of generations has gained space in literature (DANTE and ARROYO, 2017).

The social interference of generations relates to the careers and paths taken according to distinct needs and perspectives of each age group. Also, it is important to notice their historical and cultural particularities (DANTE and ARROYO, 2017). The study of generations in the labor market is crucial due to the differences observed in terms of thinking, acting, and seeing the world (COMAZZETTO, VASCONCELLOS, PERRONE et al., 2016).

\section{Baby boomers}

Baby boomers are the demographic cohort born between 1946 and 1964, a period called in Brazil as the "golden years." In general, baby boomers witnessed in their youth the beginning of the cold war and the debate on nationalism based on the struggles in Vietnam (SANTOS, 2011). The designation 'Baby Boomers' was used because of the positive postwar scenario, marked by a time of an extraordinary increase in the global birth rate. Children who were born and lived in this period were subjected to strict discipline in their studies and work, being rewarded when following the established values (OLIVEIRA, 2010).

Among the characteristics of baby boomers, stands out the widespread belief that professional advancement is a result of hard work alone, therefore, their need to fulfill the obligations with excellence. Baby boomers are among the best business leaders in the world because of their ability to conduct business responsibly, and ethically perform their professional roles (OLIVEIRA, 2010; LANCASTER and STILMAN, 2011; VELOSO, DUTRA and NAKATA, 2016). 


\section{Generation X}

Generation X refers to the demographic cohort born between 1965 and 1981. They are responsible for a period of evident changes, as they rebelled against the values established at the time (OLIVEIRA, 2010). Generation Xers adopted a distrustful stance as they grew up at a time marked by corporate downsizing. The administrative restructuring in the market affected labor relations, undermining the relationship between loyalty to the company and job security.

Generation Xers were oriented to develop skills to improve employability, as there was no longer confidence in functional stability (VELOSO, DUTRA and NAKATA, 2016). Generation Xers are autonomous people who care to make a difference as long as they are doing what they like. Moreover, due to technological development, they are less patient with activities demanding time (BRANCO, 2013).

\section{Millennials (generation Y)}

'Millennials,' are the demographic cohort born between 1982 and 2000. In Brazil, at this time, the country was experiencing substantial economic instability, followed by the process of democratic transition, with the enactment of the federal constitution of 1988. Globally, the culture of transience and lack of guarantees of rights prevailed, as well as markets characterized by volatility (VELOSO, DUTRA and NAKATA, 2016).

Millennials are driven by their expectations, hoping for immediate professional advancement. They are professionals likely to move from one company to another when they do not feel challenged and do not recognize opportunities to progress in their career (GRASSI, DE ANDRADE and VELOSO, 2016).

\section{METHODOLOGY}

The study adopted a qualitative and descriptive-analytical approach (CERVO and BERVIAN, 1983; COLLIS and HUSSEY, 2005), interviewing 32 female managers from organizations in the areas of banking (09 interviewees), technology (10), and in the public sector (13), in the city of Belo Horizonte (MG), Brazil. Table 1 shows the sociodemographic profile of the interviewees. The article identifies their contribution using "I01", "I02", ... up to "I32".

Table 1

Identification per generation E1 - E32

\begin{tabular}{|c|c|c|c|c|}
\hline Generation & Born between & Current age & Interviewees & Total \\
\hline Baby Boomers & 1946 to 1964 & 54 to 72 years & $114,128,129,130,131,132$ & 06 \\
\hline Generation Xers & 1965 to 1981 & 37 to 53 years & $\begin{array}{l}102,103,107,110,111,113 \\
119,121,123,124,126\end{array}$ & 11 \\
\hline Millennials & 1982 to 2000 & 18 to 36 years & $\begin{array}{c}101,104,105,106,108,109,112,115 \\
116,117,118,120,122,125,127\end{array}$ & 15 \\
\hline Total & & & & 32 \\
\hline
\end{tabular}

Source: Research data.

The interviewees were separated by generations, with six baby boomers, eleven generation Xers, and fifteen millennials. As for the marital status, $62.5 \%$ of the interviewees were married, $25 \%$ single, and $12.5 \%$ divorced. The majority (53\%) of them had no children, $28 \%$ had two, $16 \%$ had one child, and only one interviewee had three children. Regarding education, 
$97 \%$ had a college degree (just one interviewee had only finished high school). Of the interviewees, $22 \%$ had a specialization/ MBA, 13\% were pursuing a master's degree, and one interviewee had a master's degree.

A semi-structured script was used to support the interviews, ensuring that the specific objectives of the study would be addressed. The interviews were applied according to the availability of the managers in a location they chose. With the consent of the participants, the conversations were recorded and then transcribed. The interviewees were selected intentionally and based on accessibility (LAVILLE and DIONE, 1999). The unit of analysis was the relationship of the interviewees with the managerial practice in the process of building identity.

The process of treating the data included recording the interviews, transcribing, and organizing the content according to a semi-structured script of questions, grouping the answers by dimension for each question. The content of the interviews was treated through a qualitative tabulation, in which the answers were identified and grouped according to the topic of the question, organized in tables. The qualitative data was analyzed based on the techniques suggested by Minayo (2000) and perfected by Melo (2002).

The data were organized in a spreadsheet, grouping the most significant content collected according to the dimensions of Hill (1993) used to conduct the analysis: a) learning what it means to be a manager; b) developing interpersonal judgment; c) gaining self-knowledge; d) coping with stress and emotions; and e) managing the transformation.

\section{PRESENTATION AND ANALYSIS OF DATA}

The research was analyzed based on the five dimensions proposed by Hill (1993) in her study with professionals in their first year working in a managerial function. In this study, the 32 female managers interviewed had been in their positions for different amounts of time: nine of them had been working for up to one year; four had been managers for up to two years; five for a period of three years; two for four years; one for five years; three for six years; three for seven years; one for eight years; one for nine years; two for ten years; and one for sixteen years.

\section{Being a manager according to the interviewees}

For Hill (1993), being a manager means being prepared to perform managerial functions. The author says that the manager needs to understand the difficulties and the probable conflicts surrounding the activities of the position, i.e., there is a learning process to go through. Interviewees from all generations agreed regarding the managerial function: It is a job with lots of responsibility. The participants pointed out the need to gain knowledge in several areas to be able to perform the role, as observed in the statements below.

A lot of responsibility [...] knowing how to relate, knowing how to deal with everyday problems [...] dealing with people, knowing how to delegate [...] (I31, baby boomer).

[...] it represents responsibility [...] to know each one, know their competencies very well and to make the best use of each one's talent [...] leading by example [...] being a leader represents this opportunity to also be participating in the decisions that the company will make [...] (13, generation Xer).

[...] Being a manager is an extreme responsibility [...] clients always have you as a reference, both for very good things, and for very bad things, so being a manager is a very big responsibility [...] (19, millennial).

While performing the managerial function, the professional must develop other characteristics such as building networks, managing subordinates, developing a broad view of the organization, as well as working to meet and assimilate the needs of the operating network (HILL, 1993). The interviewees presented these characteristics when discussing the 'definition 
of being a manager.' The interviewees see the urgency of performing multiple functions in management such as keeping the team together and productive, being up-to-date with daily events, and keeping in touch with other institutions of the same level.

[...] a consequence of a career built over the years, you know? [...] of work, it did not happen by chance, it was a construction [...] through this position I can exercise something I like, that is, to help people $[\ldots](130$, baby boomer).

[...] Liking what you do [...] liking people, I mean empathy (17, generation Xer).

It's very important [...]. It subsidized my life [...] my survival, my projects, my leisure time [...] (I18 millennial).

In the analysis of this dimension, the common perception of "being a manager" was strongly connected to "responsibility," a principle mentioned by the baby boomers, generation Xers, and millennials. However, it was observed that the opinion of the interviewees shows different stages of being a manager, which reflects the time spent in the position and indicates that the job requires a constant and evolutionary learning process, reverberating in building the managerial tools.

The statement of baby boomer 130 indicates that the manager connects "being a manager" with a process, "a career built over the years." She expressed the process of building the identity of the professional manager. Generation Xers and millennials indicated facing the position of manager as a means to achieve personal success and a step in pursuing their goals in life, admitting that it is essential to enjoy working life.

\section{Developing interpersonal judgment}

In this dimension, according to Hill (1993), managers learn to exercise authority without the specific support of formal authority. They develop the actions of control and delegation and are empowered to carry out interpersonal judgment. According to the interviewees, it is essential to create an interpersonal relationship with the work team, involving clear communication, flexibility, humility, and humanity, considering that managerial functions entail enjoying working with people.

[...] dealing with people [...] the clarity of communication, careful listening, also the clarity of the mission, you have a leadership role based on being kind, and not based on authority [...] (130, baby boomer).

$[\ldots]$ humility [...] have this feeling about learning [...] know how to listen, know how to ponder, not be impulsive [...] have knowledge [...] have humanity [...] do things right [...] be fair [...] (I13 generation Xer).

[...] it is respect, it is about knowing how to understand, how to listen, speak more sensibly [...] (I9, millennial).

Rodrigues (2016) argues that daily events and the implications of relationships established are among the aspects that constantly influence the process of building professional identity. Dubar (2005) also mentions relationships as one of the elements in building managerial identity. The author adds the influence of personal and interpersonal judgment in this process. Managers express the importance of developing a good interpersonal relationship with the work team - showing respect, humility, understanding, dialogue, among other characteristics -, and also stated that the managerial function demands strong will and flexibility.

[...] We have to be strong-willed, you have to know your work environment, know people, you have to be firm in your decisions, but you also have to be a flexible person [...] (I28, baby boomer).

[...] knowing how to work in teams, have good communication, good interpersonal relationships, clear verbal communication, really being able to make decisions [...] be flexible $[. .].(I 3$, generation Xer).

[...] we have to be down to earth [...] to be able to have this authority, do the sector management, this management, I have to have a proper structure for it, it's no use just wanting to be the authority, be the manager without listening to people, without having this good relationship (I12, millennial). 
As presented by Hill (1993), managers seek to establish a good interaction with subordinates. In the second dimension of analysis, managers from all generations prioritize the good relationship with the work team, seeking mutual respect, discussing the exercise of authority over subordinates. Managers of all generations analyzed mentioned that there is a need to act not only firmly in their decisions, but with respect, flexibility, and understanding, since managing people while respecting differences is a path to gain the team's respect and credibility. Melo (2002) considers that managers should play a political role in reconciling interests through their interpersonal relationships.

"Being a manager" involves 'juggling' between establishing good relationships and exercising authority. Millennials interviewed did not mention the issue of authority directly, even though it was possible to infer that this group recognizes authority as an important aspect of the function. This approach of the millennials toward the issue may reflect the time these managers have been in their position. The expression that represents a metaphor of the managerial identity of this group is "I am being a manager," with the connotation of a process and a temporary position. As for the managers who are part of generation $X$, the issue of exercising authority is expressed in the decision-making process, which represents the synthesis of their managerial capacity and responsibility. The metaphor is the expression "I am a manager," with the connotation of defining the professional. Finally, managers who are baby boomers had already incorporated managerial identity and clearly expressed this identity through the metaphor "I know how to be a manager."

\section{Gaining self-knowledge}

The third dimension proposed by Hill (1993) discusses the issue of gaining self-knowledge. The dimension is about the awareness of the professional regarding their role as manager and their roles in personal life. Based on this perspective, earlycareer managers are starting to learn about their professional role. Over the years, these professionals will be more than mere specialists and become professionals who master the issues surrounding the organization.

The study revealed that, although managers argue that the managerial function requires a good development of interpersonal relationships to achieve positive results, they point to these relationships as their biggest challenge.

[...] One of the biggest difficulties we encounter in the area of management is the relationship with people, this is the most delicate area. [...] (I30, baby boomer).

[...] people accepting me as I am, and facing the management in another way [...] because I am younger than the other managers [...] (124, generation Xer).

[...] It is a little difficult to establish this hierarchical relationship internally within the company (14, millennial).

Ventura and Mageste (2016) point out that being a manager is a challenge because the function entails facing unstable situations and conciliating various interests around an organization. Among other aspects, it is necessary to take into consideration and understand the issues around power relations within organizations, as well as the setbacks regarding the balance between the role as manager and the personal and family matters.

\section{Coping with stress and emotions}

The fourth dimension of analysis refers to a phase where managers are more experienced in the nuances of the position, as they have already experienced the dilemmas and recognized the sources of stress (HILL, 1993). The sources of tension are intrinsic to the managerial role and, therefore, managers must learn how to cope with them and the emotions arising from such conflicts. The data collected revealed that stressful situations are part of the interviewees' routine.

$[\ldots]$ It's in the pressure, it's in the quantity... in the diversity of tasks [...] people you have to deal with [...] (I14, baby boomer).

$[\ldots]$ it is delivering the expected result; it is the satisfactory people management $[\ldots]$ (I3, generation Xer).

The stress, the time, the pressure, the 'now.' If there is a rapid demand from one moment to another, and how difficult it is responding it all in a short time and with the best quality [...] we are never sure what the other will reply because it is unpredictable [...] (15 millennial). 
In the statements shown above, it is possible to observe the pressure for results that managers inflict on themselves, a pressure that seems to make them feel uncomfortable. All women researched showed that they feel stressed when pressured to achieve the expected result, for themselves and the others in the organization. "We will never be sure what the others will deliver, it is unpredictable" (15, millennial). Dubar (2005) confirms that building identity is a process that depends on judgment both personally and from others. The analysis showed that the stress arising from pressure for timely results and achievement of goals is common to all managers regardless of the generation.

In addition, the interviews revealed other stressors such as the lack of resources available in the organization, unreached goals, an overload of activities, and troubled interpersonal relationships. In this context, Ybema, Keenoy, Oswick et al. (2009) idealize that the construction of managerial identity is a complex process, full of facets, which presents a temporary and socially negotiated result, through the dynamic coexistence of internal struggles and external obligations. In this dimension it is worth reinforcing the issue of the relationships established while exercising the managerial function as stressors since, as mentioned before, building identity is a result from the experiences lived in relationships and from personal judgments and the judgment of others (DUBAR, 2005).

\section{Managing the transformation}

In the dimension 'managing the transformation,' managers present the process of becoming a professional manager. According to Hill (1993), the individual ceases to be a professional that operates tasks and assumes a managerial position, with a broad view of the organization. The interviewees, regardless of the generation, consistently manage this transformation through being updated, searching for more formal education, and recognizing the importance of networking:

$[\ldots]$ you have to look for networking $[\ldots]$ you always have to study and being updated [...] $(114$, baby boomer).

[...] studying, researching, the Internet, seeing a case here, what is it there, exchanging ideas with other managers $[\ldots]$ (12, generation Xer).

$[\ldots]$ It's always looking for what's coming next [...] now I'm doing another MBA in business [...] studying, researching $[\ldots]$ absorbing what he (the boss) tells me because I think I learn a lot [...] (I6, millennial).

In the process of managing the transformation and construction of managerial identity, the interviewees consider that it is essential to learn from everyday problems, as well as to seek support from their peers, always promoting an open dialogue with the work team. In this direction, when Fayol (1964) discussed managerial function, he pointed out that managers should permanently seek gains using all the resources the company makes available to obtain the best results for the organization.

The analysis of this dimension showed that managers from all generations manage the transformation process - from simple task performers to professional managers - constantly seeking to improve professionally. It is a daily process due to the changes that occur in all areas of society. Esther and Melo (2008) corroborate this finding, clarifying that identity cannot be considered a static issue, due to the constant changes in time, history, politics, and in other areas. Building managerial identity is a process that takes different paths according to the generation of the manager, reaching a similar identity for all generations. Therefore, it is possible to say that "being a manager" is above the particularities of the age groups.

\section{FINAL CONSIDERATIONS}

This study discussed the construction of managerial identity of female managers who are baby boomers, generation Xers, and millennials, using the dimensions of analysis proposed by Hill (1993) (learning what it means to be a manager; developing interpersonal judgments; gaining self-knowledge; coping with stress and emotions; managing the transformations). The managers who participated in the study, regardless the generation, were professionals concerned with formal education most have higher education, with a completed or in-progress specialization or master's degree, and their statements express the need for constant updating as a primary requirement for the managerial function. 
Managerial functions entail responsibility, which is an aspect cited many times during the interviews. The managers expressed satisfaction and seem to enjoy their work roles, pointing out that the function requires extreme dedication, daily struggles, and flexibility ('juggling'), and proactivity.

Regarding the dimension 'developing interpersonal judgment,' it was possible to observe that managers from all generations do not rely solely on formal authority to perform the managerial function. The interviewees agree that respect and authority must be earned through dialogue and good team relationships, and never through imposition. Aspects that were cited by the majority of the interviewees were: be clear in communication and flexible in decision making, be humble, seek to know subordinates, and never be impulsive.

In the dimension 'gaining self-knowledge,' the analysis showed that, at this moment of their career, the professionals have the opportunity to develop self-knowledge both as a person and as a manager. In this aspect, the study found that the most significant difficulty faced by the interviewees is the relationship with subordinates and peers. The researched group emphasized that interpersonal relationship is undoubtedly the main factor of stress in the organization, apart from the significant complexities that are inherent of the managerial function.

The process of building managerial identity involves many issues, so managers must develop skills to circumvent the situations that arise in everyday life and manage the necessary transformations in the managerial function. All interviewees mentioned the need to keep up to date and seek knowledge both in formal education (academia), and informally, by learning in the relations with peers and promoting open dialogues with the work team.

Thus, it was possible to verify that professional identity permeates various issues, difficulties, achievements, the feeling of accomplishing life goals, and going through the dilemmas inherent to the managerial functions. As observed both in the theoretical framework presented and in the empiric results of this research, although people from different generations have distinct characteristics such as the way of thinking, acting, and seeing the world, there is a common ground when it comes to building professional identity as managers and the way they perform managerial functions. This means that the managerial function presents intrinsic characteristics that are above other aspects of the process of becoming a manager, which leads to the conclusion that the particularities of each generation seem to have little influence on the process of building the managers' professional identity. 


\section{REFERENCES}

ALLARD-POESI, F. Dancing in the dark: Making sense of managerial roles during strategic conversations. Scandinavian Journal of Management, v. 31, n. 3, p. 338-350, 2015.

ALVESSON, M.; ASHCRAFT, L. K.; THOMAS, R. Identity matters: Reflections on the construction of identity scholarship in organization studies. Organization, v. 15, n. 1, p. 5-28, 2008.

BRANCO, V. F. C. A gestão da geração Y nas organizações. Rio de Janeiro: Qualitymark, 2013. p. 80.

BROWN, A. D. Organization studies and identity: Towards a research agenda. Human Relations, v. 54, n. 1, p. 113-121, 2001.

CERVO, A. L.; BERVIAN P. A. Metodologia científica. São Paulo: Mc Graw-Hill, 1983. p. 53-59.

COLLIS, J.; HUSSEY, R. Pesquisa em administração: um guia prático para alunos de graduação e pós-graduação. Porto Alegre: Bookman, 2005.

COMAZZETTO, L. R. et al. A geração Y no mercado de trabalho: um estudo comparativo entre gerações. Revista Psicologia: Ciência e Profissão, v. 36, n. 1, p. 145-157, 2016.

COSTA, A. M. N. O campo da Pesquisa Qualitativa e o Método de Explicação do Discurso Subjacentes (MENDS). Pontifícia Universidade Católica do Rio de Janeiro 2007. Available at: <www.scielo.br/scielo. php?pid=S0102-79722007000100009\&script=sci_abstract\&tIng=pt $>$. Accessed on: July 18, 2019.

COUPLAND, C.; BROWN, A. D. Identities in action: Processes and outcomes. 2012.

DANTE, F. S.; ARROYO, R. F. Âncoras de carreira: por onde caminham as gerações? Revista de Carreiras e Pessoas (ReCaPe), v. 7, n. 2, p. 512-528, 2017.

DUBAR, C. A socialização: construção das identidades sociais e profissionais. Porto: Porto, 1997.

ÉSTHER, A. B.; MELO, M. C. O. L. A construção da identidade gerencial dos gestores da alta administração de universidade federais em Minas Gerais. Cadernos EBAPE.BR, Rio de Janeiro, v. 6, n. 1, p. 1-17, 2008.

FAYOL, H. J. Administração Industrial e Geral. São Paulo: Atlas, 1964.

FALASTER, C.; FERREIRA P.M.; REIS C. Atributos que atraem a geração Y na escolha do emprego ideal: uma análise a partir da perspectiva de estudantes veteranos. Revista Contemporânea de Economia e Gestão, v. 13, n. 3, p. 2-22, 2015.

GRASSI, J. A.; DE ANDRADE, M. S.; VELOSO, E. F. R. Gestão de gerações em sistemas bancários. Revista Competitividade e Sustentabilidade, v. 3, n. 1, p. 11-27, 2016.

HILL, A. L. Os novos gerentes: assumindo uma nova identidade. São Paulo: Makron Books, 1993.

KOTLER, P. Marketing for Non-profit Organizations. 2. ed. New Jersey: PrenticeHall, 1982.

KRUGER, M.; SAAYMAN, M. Consumer preferences of Generation $Y$ : Evidence from live music tourism event performances in South Africa. Journal of vacation marketing, v. 21, n. 4, p. 366-382, 2015.

LANCASTER, L. C.; STILLMAN, D. O Y da questão: como a geração Y está transformando o mercado de trabalho. São Paulo: Saraiva, 2011.

LAVILLE, C.; DIONNE, J. A construção do saber: manual de metodologia da pesquisa em ciências humanas. Porto Alegre: Artmed; Belo. Horizonte: UFMG 1999.
LOK, J. Institutional logics as identity projects. Academy of Management Journal, v. 53, n. 6, p. 1305-1335, 2010.

MELO, M. C. O. L. Dificuldades de implementação de uma nova função gerencial: alguns resultados e reflexões. Belo Horizonte: CEPEAD/DCA/UFMG, mimeo, 1994.

MELO, M. C. O. L. A gerência feminina em empresas do setor industrial mineiro: inserção, vivência e desafios. 2002. 196 f. (Relatório de Pesquisa) - Núcleo de Relações de Trabalho e Tecnologias de Gestão, Universidade Federal de Minas Gerais, Centro Nacional de Desenvolvimento Cientifico e Tecnologia, Belo Horizonte, 2002a.

MELO, M. C. O. L. Reflexividade e a dinâmica da ação gerencial. In (org.). Gerência em ação: singularidades e dilemas do trabalho gerencial. Rio de Janeiro: FGV, 2005.

MINAYO, M. C. S. O desafio do conhecimento: pesquisa qualitativa em saúde. 7. ed. São Paulo: Hucitec; Rio de Janeiro: Abrasco, 2000.

MINTZBERG, H. The nature of managerial work. New York: Haper Row, 1973.

MINTZBERG, H. Managing: desvendando o dia a dia da gestão. Tradução de Francisco Araújo da Costa. Revisão Técnica: Roberto Fachin. Porto Alegre: Bookman, 2010.

OLIVEIRA, S. Geração Y: o nascimento de uma nova versão de líderes. São Paulo. Intregrare, 2010.

PAIVA, K. C. M. et al. Milícias, malícias e delícias da função gerencial: o setor hoteleiro em foco. Turismo em Análise, v. 17, n. esp., p. 116141, Jan. 2006.

SILVA, J. R. G. Profissionais qualificados e experiências de autoemprego: questões de tempo e espaço. In: ENCONTRA DA ANPAD, 30., 2008, Salvador. Anais... Salvador: ANPAD, 2008.

VENTURA, R. C. M. O.; MAGESTE, G. S. Trabalho gerencial: uma análise teórica das dimensões que o cercam. In: SEMINÁRIO CIENTÍFICO DA FACIG, 2., 2016, Coqueiro. Anais... Coqueiro: FACIG, 2016. Available at: <http://pensaracademico.facig.edu.br/index.php/semiariocientifico/ article/view/112/93>. Accessed on: Sept. 01, 2017.

RODRIGUES, A. B. G. C. Impactos da prática da gestão na identidade de um docente do ensino superior. In: ENCONTRO INTERNACIONAL DE FORMAÇÃO DE PROFESSORES, 9., 2016, Sergipe. Anais... Sergipe: ENFOPE, 2016.

SANTOS, A. L. A Geração Y nas organizações complexas: um estudo exploratório sobre a gestão dos jovens nas empresas. 2012. Dissertação (Mestrado em Administração) - Faculdade de Economia, Administração e Contabilidade, Universidade de São Paulo, São Paulo, 2012. Available at: <www.teses.usp.br/teses/disponiveis/12/12139/tde-30032012153841/pt-br.php>. Accessed on: June 12, 2017.

STRAUSS, W.; HOWE, N. Generations: the history of America's future, 1584 to 2069. New York: William Morrow and Company, 1991.

VELOSO; E. F. R.; DUTRA, J. S.; NAKATA, L. E. Percepção sobre carreiras inteligentes: diferenças entre as gerações $Y, X$ e Baby Boomers. REGE - Revista de Gestão, São Paulo, v. 23, n. 2, p. 88- 98, 2016.

YBEMA, S. et al. Articulating identities. Human Relations, v. 62 , n. 3, p. 299-322, 2009. 
Senior scholarship holder from CNPq; Full Professor at the University Center Unihorizontes; Professor (retired) at the Federal University of Minas Gerais (UFMG); Rector of the University Center Unihorizontes. PhD in Organizations Science from the Université Paris IX - Dauphine (France), master's in Administration (Administration and Industrial Relations) from the Department of Administration Science of the UFMG, specialization - Diploma de Estudos Aprofundados (DEA) (specialized studies diploma) - from the Université Paris IX - Dauphine, and bachelor's degree in social communication - journalism from the Faculty on Philosophy and Humanities of the UFMG; Coordinator of the Núcleo de Relações de Trabalho e Tecnologia de Gestão (NURTEG) (research group on working relations and managerial technology), Belo Horizonte-MG, Brazil. E-mail: marlene.catarina@unihorizontees.br

Vilma Santos Pereira de Faria

ORCID: https://orcid.org/0000-0002-0293-120X

Master's degree in Administration and bachelor's degree in Accounting from the University Center Unihorizontes; Professor and researcher at the Núcleo de Relações de Trabalho e Tecnologia de Gestão (NURTEG) (research group on working relations and managerial technology), Belo Horizonte -MG, Brazil. E-mail: vilma.santos@unihorizontes.br

\section{Ana Lúcia Magri Lopes}

ORCID: https://orcid.org/0000-0001-6012-9621

Master's degree in Administration and bachelor's degree in Administration from the University Center Unihorizontes; Coordinator of institutional evaluation and member of the Comissão Própria de Avaliação (CPA) (commission of self-evaluation) of Unihorizontes; Professor and researcher at the Núcleo de Relações de Trabalho e Tecnologia de Gestão (NURTEG) (research group on working relations and managerial technology), Belo Horizonte -MG, Brazil. E-mail: ana.lopes@unihorizontes.br 